University at Buffalo School of Law

Digital Commons @ University at Buffalo School of Law

Fall 2008

\title{
The Social Life of Regulation in Taipei City Hall: The Role of Legality in the Administrative Bureaucracy
}

Anya Bernstein

University at Buffalo School of Law

Follow this and additional works at: https://digitalcommons.law.buffalo.edu/journal_articles

Part of the Administrative Law Commons

\section{Recommended Citation}

Anya Bernstein, The Social Life of Regulation in Taipei City Hall: The Role of Legality in the Administrative Bureaucracy, 33 Law \& Soc. Inquiry 925 (2008).

Available at: https://digitalcommons.law.buffalo.edu/journal_articles/58

This is the peer reviewed version of the following article: Anya Bernstein, The Social Life of Regulation in Taipei City Hall: The Role of Legality in the Administrative Bureaucracy, 33 Law \& Social Inquiry 925 (2008), which has been published in final form at https://doi.org/10.1111/j.1747-4469.2008.00128.x. This article may be used for noncommercial purposes in accordance with Wiley Terms and Conditions for Use of Self-Archived Versions.

\section{IN COPYRIGHT}

This Article is brought to you for free and open access by the Faculty Scholarship at Digital Commons @ University at Buffalo School of Law. It has been accepted for inclusion in Journal Articles by an authorized administrator of Digital Commons @ University at Buffalo School of Law. For more information, please contact lawscholar@buffalo.edu. 
The Social Life of Regulation in Taipei City Hall: The Role of Legality in the Administrative Bureaucracy

Anya Bernstein

anyabernstein@gmail.com

40 Foster St. 2nd Fl.

New Haven CT 06511

(203) 752-1977

Anya Bernstein received a Ph.D. in Anthropology from the University of Chicago in 2007 and is now a J.D. student at Yale Law School. She can be reached at anyabernstein@gmail.com. Many thanks to Christopher Tomlins and Elizabeth Mertz, as well as two anonymous reviewers, for their comments.

12,037 words / 59 pages 
This article explores the role of legality in conceptions of state and society among bureaucrats in the Taipei, Taiwan city government. When administrators see Taiwan in the global arena, the existence of law provides an emblem of modernity and the ability to participate in the international system. In interactions among administrators, law is laden with impossible ideals and fraught with assumptions of hypocrisy. In dealings with people outside the government, legality often signals the breakdown of other, more valuable, social norms. Far from legitimating administrative action, legality itself is legitimated by reference to the same values as other social action: held up to an ideal of consensus and cultural coherence and judged by its ability to fulfill obligations and nurture relationships. Law does not hegemonically structure administrators' conceptions of state and society. It defines one aspect of governance at the margins of legitimacy, dependent on justification through other ethical norms. 


\section{THE DIFFERENTIATED ROLE OF LAW IN ADMINISTRATION}

As a postcolonial, post-dictatorial, recently democratized country, Taiwan presents a best-case scenario of regime change. ${ }^{i}$ The role of the newly representative state in this society thus has much to teach us about the cultural specificity of democracy, even in the relative absence of the military, social, ethnic, and economic upheavals that often accompany democratic transition. The state democratized both through low-level voting from below and through executive fiat from above. It did so with relatively little violence or social upheaval (Rigger 1999; Kuo 2000; Chao and Meyers 1998; Chang et al. 1997). And it did so quickly, with freedom of speech, association, movement, and political party formation taking root quickly with the end of forty years of martial law in 1986-87. Within ten years (1996), the country had had its first multiparty presidential election; within four more (2000), it witnessed a peaceful handover of presidential power from the ruling party (the KMT) to the opposition (the DPP). ${ }^{\text {ii }}$

While tensions among local ethnicities continue to provide fodder for political rhetoric, they have been greatly eased through decades of intermarriage and school and workplace integration. Even at their height, they did not reach the level of social division and violence experienced in many other post-colonial and post-dictatorial societies (Rigger 2006, 2000; Chang 1994; Wong 2001; Johnson 1992; Corcuff 2002, 2000) ${ }^{\text {iii }}$ Finally, while racing through stages of economic development, the country avoided the economic polarization that often 
accompanies rapid growth, fostering a large middle class and a generally broad wealth distribution (Tien 1989; Ho 1987; Gold 1986).

Studies of Taiwan tend to show a strong state with a weak legal system. While state policies have been central to Taiwan's remarkable prosperity in the post-War period (Amsden 1985), the power of the law in everyday life has been shown to be "marginalized" (Winn 1994; Martin 2007). The process by which the Taiwanese state took on its contemporary form gives some indication of how this disequilibrium between state and legal power emerged (Bosco 1992; Winckler 1981, 1984). Like most successful political developments, that process drew on the terminology of existing cultural norms and understandings to fit into existing social continuities (cf. Duara 1988), while creating powerful new trends of its own (Wu 1987).

This article builds on these lines of research to examine the role of law in the work of government administrators. I situate my inquiry within the administrative bureaucracy itself. This is a relatively unusual place for ethnographic inquiry, which tends to focus more on the people controlled, described, or excluded by state processes than on the people implementing them. But taking seriously those outside of, marginalized by, or victimized by bureaucracy should not mean taking less seriously those working inside it. In valorizing everyday life, social scientific research has sometimes proceeded as 
though everyday life occurred only at the margins of power, not in its centers (cf. Valverde 2003).

Michel Foucault's evocative phrasing captures this suspicion of focusing on the sovereign center: the study of legality and legitimacy developed, in his terms, as the study of the rights of the King (Foucault 1980)..${ }^{\text {iv }}$ But rather than abandoning the state, I focus on its own capillary dimensions. Placing my inquiry within the bureaucracy also, I believe, helps me avoid conflating the state, as a social organization, with its laws, which are after all only one way the state expresses itself. To illuminate its other modes of expression, I focus on the everyday life of the state itself: as ethnography, my study relies primarily on the unremarked-upon actions and words of the administrators with whom I worked.

I draw my material from my dissertation research, an ethnographic study that moved between the Taipei City Government's Department of Urban Development and a small, politically active Taipei neighborhood (Bernstein 2007). For the administrative part of my research, I spent three months reviewing documents and holding formal interviews and informal conversations with administrators at the Department of Urban Development's small outpost office devoted to urban renewal. The outpost office then housed approximately five administrators, in contrast to the roughly hundred and fifty working the central City Government office. I then spent approximately six months working, mostly as a full-time volunteer, in the department's central office in Taipei City 
Hall. I was already familiar with many of the administrators I encountered from my previous year of work with neighborhood activists. As the department's English language consultant, I was assigned to a departmental section that employed around fifteen to twenty administrators (the numbers changed due to normal turnover and because of a departmental reorganization that occurred in the middle of my fieldwork). Officially housed in this administrative location, I worked with administrators; sat in on their daily meetings with other government employees, consultants, and members of the public; and traveled with them for on-site inspections, long lunch outings, meetings, weekend hikes, and other activities outside the office.

In this context I recorded roughly thirty hours of open-ended, semistructured interviews with administrators at every level of the departmental organization, from department head to low-level functionary, with a focus on the planning and implementation sections of the department. In addition to recorded interviews, I conducted hundreds of conversations with administrators from across the department, as well as many in other city government departments. Like many anthropologists, I find that the most meaningful parts of my material do not come from interview sessions, set apart as they were from normal life by time, place, and the presence of the microphone. The ethnographic method of participant observation asks the researcher to spend time living with and like the people she studies, noting the often unnoted patterns of their lives. Accordingly, 
my primary material came not from the stories people told when asked to tell stories, but from the off-hand remarks, the unreflective answers, and the commentaries on ongoing events that characterize the Department of Urban Development's lively and voluble social life. My coworkers, moreover, graciously took my presence in stride, allowing me to accompany them as they went about their tasks and pausing in their work to discuss what they were doing. ${ }^{\mathrm{v}}$

I find that how administrators use, invoke, and present the law depends a great deal on their implied addressees. When they place Taiwan in the international context, administrators often present the legalization of everyday life as a symbol of the country's neglected ability to participate in the world system of nation-states. In intra-agency interactions, however, law is often presented as seeking an unattainable perfection; this perfect law's very implausibility encourages administrators either to ignore or to manipulate it. While at the level of global addressees law signals ripeness for participation in the world, at the level of administrative addressees it bears a faint stench of ethical rot. Far from legitimating administrative action to other administrators, the use of law must itself be justified by recourse to other values, whether the political goals of the moment or lasting social orientations. Finally, in the context of administrators' interactions with those outside the government bureaucracy, conceptions of legality often fix the extreme boundaries of allowable action. At this level, legality is invoked as providing lines beyond which one can not go. More to the 
point, one ought not to reach them in the first place. For government administrators, recourse to the law marks not only the breakdown of social process but also the failure of their administrative role.

Perhaps most importantly, much administrative practice hardly brings up the law at all. Administrators do, of course, work within the broad parameters of state regulations. But they tend to present the state they work for as a social actor, similar in fundamental ways to those with whom it interacts: subject to the same ethical imperatives and judged by the same standards as community groups, occupational organizations, and individuals. To its implementers, then, state action in Taiwan is legitimated when it fits into broader social ideals that have little to do with legality. Recourse to the law does not lend legitimacy; rather, it itself requires legitimation, suggesting as it does the breakdown of proper and desirable social functioning.

From one perspective, this may look like a lamentable 'gap' between law in action and law on the books, or between what the law promises and what it delivers. A gap-focused evaluation suggests a presupposed ideal of congruence between law as text and law as social actor, although as Stewart Macaulay (2005:390) has pointed out, few people would be interested in fully achieving that ideal. $^{\text {vi }}$ The people I worked with in Taiwan did not, for the most part, share this ethical ideal. Rather, they treated the law as only one of the languages spoken by the state, and assumed that it would play different roles in different arena. Thus 
the roles law plays for administrators at the different levels of addresseeship I discuss are more productively approached as social facts that arise from, and make sense in the context of, Taiwan's political history and its broadly held social values.

Another basis for judging the promise of the law against its product is the hegemonic role often attributed to law or its conceptualizations. As Susan Silbey (2005:332) writes, "law is powerful, and it rules everyday life because its constructions are uncontroversial and have become normalized and habitual." But the differentiated roles of law I describe also suggest that the legality's power to permeate a society, legitimate action within it, or present a background condition within which people imagine their own possibilities, remain questions for empirical research more than characteristics of law itself. My study agrees with those who suggest that understanding sociopolitical processes like legality requires attention to the different roles that law plays in the culture of different places, and to the nuances of how even similar concepts become differently embedded and meaningful in different societies (Sahlins 1999; Jacobs 2007; Feldman 2000).

\section{ADMINISTRATION AS A LOCATION FOR ETHNOGRAPHY}

Administrative bureaucracy has been an object of both fascination and derision for social scholars. Often ignored, often disparaged (Herzfeld 1992), it 
has also been acknowledged to be central to the modern governance of state and of self (Albrow 1970). From Weber's (1978) description of the role of bureaucracies in perpetuating a system of rule through time to Foucault's vision of the administrative "conduct of conduct" (Burchell et al. 1991:2) expanding outward into ever more areas of life, rational administration as organizational form and as organizing principle has been seen as one of the defining characteristics of modern governance. Recent interest has particularly focused on how institutional recognition and categorization influences individual selfconception and social structure. Scholars have shown, for instance, how administrative categories and exhortations not only affect, but also help effect, the very types of people designated to fill them (Foucault 1977; 1991). As Ian Hacking (1991) explains, the categories of administration are not simply prescription masked as description; they provide descriptions particularly available for self-descriptive purposes.

Much of the most illuminating work on administrative functioning has focused on the vector of power going from bureaucratic administration to surrounding populations, looking at the bureaucracy's power to categorize the people it administers (Cohn 1987), to speak to and for them (Errington 1995), and to enact or encourage violence upon them (Hansen 2001). Studies of the "feedback effect" of social knowledge (Hacking 1990:2) have revealed how knowledge about subjects can create, redefine, or close off participation in social 
categories (Brubaker 1996; Cohn 1987; Comaroff and Comaroff 1992; Gladney 1993; Hacking 1999). The attention of such studies has generally been weighted toward completed forms of category transformation or institutional address. Less has focused on administrators as populations of their own (though see Blau 1963; Hull 2003; Espeland 1998).

This may be because for many observers, administration seems to obviate individual agency. The humanness of the human condition seems to get lost in the forms, the routines, the shuffling of papers. For Hannah Arendt - the most compelling thinker to present both this view and reasons to reject it—bureaucratic administration is the very negation of political action. Action for Arendt (1959:25) is a term of art closely associated with politics itself. Enacted largely in speech and concerned with persuasion rather than force, action fundamentally involves direct interaction with others and is thus conditioned on "plurality" (9): the fact of living with others and their multiple perspectives. We act when we distinguish ourselves from others and have lasting, though never predictable, effects on others' lives and memories. Politics, for Arendt, involves making decisions and taking responsibility for their always unpredictable effects. The problems of modern governance arise when people cease to act and fall into the habit of going through the motions or going with the flow.

The human ability to stand out and perform then becomes dissipated into "a kind of no-man rule" instantiated in "bureaucracy" (Arendt 1959:37), where 
people are normalized and judged by their status rather than their deeds (cf. Foucault 1977). Between the euphemisms and the collectivities and the division of decision-making labor, nobody is left to take responsibility or admit unpredictability. The bureaucratization of the public realm as a whole, for Arendt, makes real political action increasingly impossible: it marks, in Bonnie Honig's (1993:116) words, a "lack of politics" because it precludes human creativity and real action. Given that view, it would make sense that action, individuality, powerful human relationships, would all be least possible in the belly of the administrative beast. Bureaucracy for Arendt, writes Hanna Pitkin (1998:79), instantiates the "abdication of human initiative and judgment" that plagues modern society. ${ }^{\text {vii }}$

But as Pitkin (1998:180) also notes, behavior and action (in Arendt's sense) do not necessarily correspond to different arenas of life (even though Arendt herself sometimes treats them this way). Rather than isolating arenas or spheres of life, these notions can describe ways of living: not a set of activities or concerns but the way one engages in some activity or has some concern. ${ }^{\text {viii }}$ Administration, in other words, does not have to act as the conceptual counterweight to political action or everyday life. If people behave like automatons or like tyrants, this second view suggests, they do so less because of the job they hold than because of the way they hold it. And indeed, actual bureaucrats in actual bureaucracies, just like people in all sorts of other settings, 
are constantly making decisions, interacting with others, exceeding their own control.

Focusing on bureaucrats entails asking how people who bear delegated responsibility for the polity frame and enact their own (and others') participation in it. Like all government administrators, the people I deal with here occupy a complex position in the representational structure of the state. They create and help implement plans and regulations, but they are also objects of - that is, subject to- those plans and regulations. The low-level bureaucrats I worked with, who constantly interact with 'the public (minzhong 民眾),' bear the burden of multilateral representation: they speak for the organizations of the state to its people, and the organizations of the people to their state. Moreover, research in my two contrasting fieldsites revealed that much more united the administrators with the community activists I knew than distinguished them. The two groups had different socioeconomic and educational backgrounds and occupied different positions in the sociopolitical world. But administrators' understandings of what constituted legitimacy in political action and organization, as well as their conceptions of the right and the good more generally, resonated with those of community activists who occasionally opposed them over specific projects. Given the complex quality of their role within the state, government administrators should be particularly interesting to ethnographic inquiry about how widespread understandings of political action and habits of political practice help structure the 
realm of cooperating and competing institutions that includes, but is not limited to, the state.

\section{CONTINUITY AND CHANGE IN THE TAIWANESE POLITY}

Law and administration in Taiwan, perhaps even more than in most other places, developed largely as a palimpsest of incoming influences. The Qing dynasty, which took over Taiwan in 1683, first ruled it loosely as "reluctant colonizers," unwilling to take on the costs of "pacifying" or extending control over the island (Eskildsen 2005:286) and willing to tolerate an ambiguous sovereignty in the frontier areas holding both Chinese migrants and indigenous inhabitants. In the late $19^{\text {th }}$ century the Qing began devoting more resources to administering, securing, and modernizing Taiwan, but this increasing administrative incorporation was brought up short in 1895 by China's surrender of the island to Japan after the Sino-Japanese War.

As Japan's first full-fledged colony, Taiwan received a great deal of legal and administrative attention. One of the first projects of the incoming government was a series of methodical studies of local customs, economic circumstances, and land relations. These studies helped support a strong, intricately organized rule that coopted local social forms and translated Japanese laws into Taiwanese terms, lending a sense of stability and continuity to a changing situation (Chang and Myers 1963; Myers and Peattie 1984; Ho 1968, 1971, 1978; Wang 2000; Ka 
1995; Ts'ai 2006). For instance, the Japanese colonial administration introduced the legal recognition of private property to Taiwan by adapting the private property portions of the Japanese Civil Code (itself based on the French Civil Code and promulgated only several years earlier) to land-use terminology already in use on Taiwan (Lee 2004:155). Similarly, the colonial legal regime retained the family farm as its primary economic unit even as it fundamentally altered the economic world in which that unit functioned by constraining farmers' choice of crops and restricting their sale (Ka 1995).

When it acquired Taiwan in 1945, the KMT inherited the administrative structure left by the Japanese colonial government; it also received training and advice from the Japanese after the war (Phillips 2003). The Party itself came with policy training from Germany and the Soviet Union (Kirby 1984; Taylor 2000), as well as considerable experience with policy experiments on the mainland (Kirby 1990; Bishai 1991; Ho 1978). During the first two decades of Nationalist rule the United States also contributed considerable financial and planning support, sometimes to the extent of drafting and holding effective veto power over economic policies (Gold 1986; Cumings 1984). More recently, the U.S. legal system has exerted influence through returning students and its generally hegemonic position in the Taiwanese international imaginary, leading to an increasing mixing of Continental and Anglo-American legal forms (Kennedy and Shen 2005; Yeh 2002; Hwang 1995). 
Jane Winn (1994:195) has suggested that this history of importing legal forms helped marginalized the law in Taiwan: the "formalism of Taiwan's transplanted version of the Western legal tradition seems to limit the law's flexibility in adapting to contemporary Taiwanese social practices." Instead of having recourse to predictable, objective legal standards, individuals remained dependent on particularistic "relational practices." Many of my interlocutors in the bureaucratic administration shared this view. For instance, Mr. Zheng, ${ }^{\text {ix }}$ a highly educated and well-respected mid-level administrator, once explained that western laws grew organically out of social norms, leading to a natural connection between the legal system and social realities. Taiwan's laws, on the other hand, were imported from America ("we like most to copy you, because that's what we know best") or from Japan ("they originally copied from Europe, so because we're so close we copied from them"). ${ }^{\mathrm{x}}$ This, Mr. Zheng concluded, left a big "gap" (he used the English word) between Taiwan's laws and its society.

KMT regime consolidation likely also played a part in marginalizing legality. Over decades of martial law rule with low-level elections, the KMT developed what Wu Nai-teh (1987) has called a "regime patronage system." That is, the regime itself was a patron in a clientelist system. The central government, coterminous with the KMT party, transferred material goods and resources to local elites, whose factions acted as clients of the central state ${ }^{\mathrm{xi}}$ Local elites in turn became patrons at the local level, transferring resources to local clients who 
lent them political support. Intra-party factions at the local level also allowed the KMT to make claims to democracy despite the actual one-party system it enforced (Bosco 1992; cf. Winckler 1981). The Party could continue local level elections with the assurance that its monopoly over resources at the central level would prevent outsiders from winning seats and allow Party elites to determine the outcomes of contested elections by playing local factions off against one another. (Rigger 1999 explains how this system eroded in the electoral arena). By routing political action through personalistic relations and small-scale local organization, the clientelist system lessened "the possibility for structural or policy change" (Wu 1987:22).

$\mathrm{Wu}(1987)$ stresses that the martial law patronage system, which utilized traditional norms and forms, was not itself a continuation or a holdover of a traditional governing system. Political factions built on other, less formalized, social groups, like kin, fictive kin, and student organizations, and used the common ethical terminology of affective links and long-term relations of mutual aid and mutual obligation to render the personal indistinguishable from the political. The linguistic and conceptual terminology of traditional values helped naturalize this new political system, which itself was a modern phenomenon: centralized, bureaucratized, and instituted to consolidate Party control over the polity at different levels of social organization. Since that time, Taiwan's political system and the ways in which people can participate in or effect it have changed 
radically. But this bureaucratically entrenched form of clientelism has not disappeared with the transition to democratization. While it has become less clear who acts as client and who as patron in any given interaction, my research confirms that the personalistic mode of governance still plays an important role in Taiwanese political values and ideals.

\section{TAIPEI IN A GLOBAL CONTEXT: INTERNATIONAL ADDRESSEES}

Taiwan's chronic standoff with The People's Republic of China informs the daily activities of Taipei's administrators. The country's de facto but not de jure sovereignty remains an issue constantly brought to the fore by external circumstances, such as China's occasional threats and the periodic refusals of noneconomic international organizations to recognize Taiwan's participation in the international arena. ${ }^{\text {xii }}$ Taipei, Taiwan's capital, acts as the nation's model city, most visible to and most in contact with the rest of the world. For those charged with effecting it, the urban planning of Taipei was integrally involved with the international status of Taiwan. Administrative discussions presented the way that members of the international community perceived Taipei as intimately linked to the way that they would characterize the relation between Taiwan and the mainland. Perceptions of that relationship, in turn, were seen to indicate opinions about the place of Taiwan within the nation-state system. Administrators typically placed Taipei within a particular nexus of cultural influence and economic 
interaction: Japan (typified by Tokyo), China (typified by Shanghai), and the U.S. (typically spoken of as a whole). Questions of self-presentation to the international community permeated the planning of everything from riverside hiking paths to neighborhood renewal. Meetings about a particular building or urban area routinely started off with discussions of global economic trends affecting the Tokyo-Shanghai-U.S. nexus. Plan proposals stressed how implementation would demonstrate Taiwan's cultural specificity, economic viability, or administrative modernity to the broader world.

"We start from a global perspective," an administrator remarked at a meeting where representatives from several city and county governments discussed a proposed regional cooperation zone encompassing northern Taiwan. "[We start] from the global, to Asia, to Taipei, Tokyo, [and] Shanghai, to understand what role the northern Taiwan region should play." The regional cooperation initiative was a nascent project aimed at overcoming the barriers to effective administration raised by democratic elections, which had for the first time allowed the region's city and county governments to be governed by mayors from different parties. Intense competition at the level of the national parties inhibited infrastructural and environmental cooperation among these geographically and economically connected areas. Searching for starting points for regional integration, administrators remained vocally aware of the international situation of their plans. 
Like their colleagues throughout the Department, these administrators placed the northern Taiwan region they were trying to create firmly within an international context. The creation of political and infrastructural connections presented not only a practical domestic concern but acted as a symbol of Taiwanese cultural and social coherence. In the dramatic phrasing of one of the department's consultants, administrators were attempting to construct the city's and the regions "self (ziwo 自我)." Echoing the laments of many administrators, this consultant began a planning proposal presentation by explaining that "from the [central] government of the Republic of China down to the Taipei city government, nobody knows what the self is." He referred, of course, not to a psychological entity but to a territorial identity. Governmental agencies at all levels in Taiwan, he implied, had failed to come up with a concise, coherent formulation of identity in terms of which their projects could be justified and their realities explained and assessed.

Mr. Wei, a high-level administrator, agreed when he summed up what was wrong with his city. "We have no consensus," he declared. "We can’t even have a discussion about how Taipei should be." Describing the problems of determining the formal status of cities within a country not formally recognized as a nationstate, he continued: "Is Taipei a capital city? Of course it's a capital city. Do you dare say it's a capital city? You don't dare." Moving from the clearly political to the culturally symbolic, he went on: "Even deciding if mountainside buildings 
should have sloped roofs, even [on] that we can't get consensus." Sloped roofs, of course, are a standard feature of traditional Chinese architecture, and part of the lacking consensus is on the relevance of China and Chineseness for Taiwan.

"We've argued about it for years."xiii For Mr. Wei, regulation provided a means to achieve a unified presentation of the city's character, boosting its international status and visibility.

As I suggest above, defining Taipei's self was important to administrators largely because of the importance of cultural self-definition in international understandings of national self-determination. Administrators, like other politically aware people in Taiwan, understood that the "institutional repertoire" of international opinion (in Horng-luen Wang's 2004:788 words) requires a distinct culture for every nation. That is, administrators knew that convincing claims to cultural uniqueness and historical specificity can carry more weight in international understandings of sovereignty than the manifest existence of a separately functioning state or economic system. Wang (2004:812) described the unsettled nature of Taiwan's political and cultural institutions by noting their common failure to "perform the social magic in front of outsiders to signify "who they are' in an affirmative manner." In this context, legality becomes a cultural characteristic that helps administrators perform this "rite of institution" (Bourdieu 1995). Looking outward, the development of Western-style laws suggests Taiwan's ability to conform with Western notions of modernity, and thus holds 
out a promise of international recognition This symbolic importance of legal strictures often outstrips the practical weight given their enforcement. Legality thus plays an important role in the city's self-presentation.

Ms. Zhu, a high-ranking department administrator who had played a part in the development of Taipei's zoning ordinances, demonstrated this differential importance. Taipei's first zoning laws were passed under the Japanese colonial regime (Huang 1983; Zhang 1993; Huang 1998; Allen 2000, 2005). A 1936 law introduced standardized land-use zoning to Taiwan, dividing the city into functional areas distinguished by 'positive' and 'negative' zoning requirements. Negative zoning regulations divided the city into 'regions' (diyu 地域) with limits on potential use, setting off residential, commercial, and industrial areas, areas with light industry and land held in reserve in anticipation of city expansion, and areas not to be developed, like parks (Huang 1998:112). Positive zoning regulations, which set apart 'areas' or 'districts' (diqu 地區), specified the range of allowable uses, setting up scenic, natural, fire-prevention, and sex-work areas (Zhang 1993). In the late 1970s--that is, as U.S. and U.N. recognition were moving away from Taiwan and toward the P.R.C.--the city government convened a group of experts and scholars to reformulate and update the zoning laws. The group, led by professors Taipei University (臺北大學, then called Zhongxing University 中興大學), worked on developing new zoning regulations with more 
positive - prescriptive rather than proscriptive - parameters. They finished their work in 1983 with the promulgation of the city's new zoning regulations. Their main frame of reference was the zoning system of New York City.

Ms. Zhu commented that city administrators generally would like to move Taiwan in the direction of Japan or Euro-America (Oumei 歐美) by for instance, enforcing regulations limiting commercial establishments to the first floors of streetfront buildings. But, she explained, the fact was that Taiwan's society differed greatly from that of New York City, where the ideas for these regulations had come from. Taiwanese people, for instance, were accustomed to commercial establishments occupying any given story of any given building, not only on the streetfront but in the small alleys as well. What's more, Ms. Zhu continued, Taiwanese people are generally happy with this situation. With a store or a restaurant on the floor above a residence, as she put it, "we are likely to feel not that it is a nuisance, but that it is a convenience." ${ }^{\text {xiv }}$ So although in principle administrators would like to move the city toward stricter zoning divisions, at present they didn't have the capability to separate residence and commerce very clearly. Indeed, the entire city was effectively a mixed use area. In other words, and perhaps not so surprisingly, although the laws were drawn from New York City, the society they applied to had remained that of Taipei. ${ }^{\mathrm{xv}}$

Ms. Zhu, who had worked on formulating and promulgating the zoning regulations, did not seem disturbed by the unenforceable quality of the laws she 
had helped create. Taking me step by step through the history of the zoning laws, she used the same patient, explanatory tone of voice to discuss both the regulations and the fact that they were not enforceable. In her depiction, these two aspects of the story did not appear as contradictions, nor did the latter seem to invalidate the former. For Ms. Zhu, the existence of regulations appeared to function as an indication of a larger, almost metaphysical, trend: a symbol of progress in a Euro-American direction, rather than a social force she expected to actually regulate people's activities. In conversation with this senior administrator, legality played a limited role. It was a kind of emblem indicating that the government recognized the expectations of an international community whose continued approval seems to be essential to Taiwan's ability to act as a practically, if not legally, sovereign nation (Rigger 2000). At this level, where law works as a message to international addressees, the role of law was thus not necessarily to enforce a particular vision of society, but to present it to outside observers.

This emphasis on self-presentation and self-definition through relation to more powerful external entities may be typical of the political process of many places economically, politically, or culturally marginalized places (Gal 1991). It also makes sense given the precarious juridical and military position of Taiwan in a community of nation-states that don't quite know what to make of it. In the midst of protests over the presidential election of 2004, for instance, which Chen Shui-bian won by a disputed fraction of a percentage point, the mainland Chinese 
government announced that it would consider sending its military to restore order to the island--that is, to use Taiwan's domestic turmoil as a chance to invade and occupy it. The situation in Taiwan itself looked to many observers strangely similar to that of the United States in 2000; the international reaction, however, did not. Little wonder, then, that local administrative action is often colored by cross-Straits relations and international expectations. Little wonder that government administrators work to carve out a recognizably unique place for Taiwan, summarized by Mr. Can's injunction to find or define Taipei's sense of self.

\section{LEGALITY AMONG ADMINISTRATORS}

Positive zoning regulations, like those developed by Ms. Zhu's group, have epistemological implications. Under the Japanese system, positive zoning regulations set off a limited number of urban areas for a highly limited number of specific uses. Most of the city was covered by negative regulations, which restricted disallowed uses. Extending positive regulations to larger areas of the city, however, required an encompassing understanding of urban society: to specify all allowable land uses in their regulations, administrators had to be able to imagine what those various land uses might be. At the same time, rapid changes in Taiwan's society and political organization--the lack of consensus described by Mr. Wei above--have led administrators to despair of knowing much 
at all. Taiwanese society, many agreed, had become too "complicated (fuza 複 雜)" to track with administrative knowledge. The encompassing intent of regulation required cumbersome legal changes to accommodate new practices and social phenomena. Administrators described this as a 'hard, unyielding (ying 硬)' quality. This hardness left administrators playing catch-up with a rapidly changing society and rendered legality unusable in many administrative situations. Even as administrators spoke of the written law as inflexibly attempting to define everything under its purview, they described even the procedures of legality as a field of compromise and uncertainty. Commenting on the chronology of legal implementation, for instance, Ms. Gu, a mid-level administrator, emphasized not the bureaucracy's ability to clearly differentiate legal from illegal behavior, but the opportunities for negotiation that even law on the books offered. Many laws having to do with land use, for instance, are put into implementational abeyance when they are passed. Implementation is suspended pending the development of associated laws and measures (peitao cuoshi 配套措施) seen as their necessary complements. Announcing a law, the government thus effectively announces only its intention to make a set of interrelated laws. This leads to a certain amount of systemic confusion about the relationship among the announcement of the original law, the development of associated laws and 
measures, and the built-in grace periods for implementation--differences, often, of years or decades.

Ms. Gu pointed to the uncertainties of the law, emphasizing the gaps or discrepancies (luocha 落差) in legal procedure. These gaps were not gaps between law on the books and law in action, but gaps within law on the books itself. As my coworkers' constant negotiations with city residents demonstrated, the very inflexibility of these legal strictures left capacious room for argument. Theories of bureaucratic functioning often emphasize the role of the bureaucracy in categorizing and defining the objects under its purview (cf. Handelman 2004). The administrators I worked with, in contrast, emphasized the structural impossibility of clear-cut categorization.

A prevailing notion that laws ought to be able to achieve the kind of encompassing and predictive capabilities needed to specify something like all allowable uses of a piece of land thus coexists with a prevailing conviction that they cannot do so. Administrators involved in creating such laws were, in a sense, confounded by their own perfectionism, as the preferred form of law insisted on a totalizing knowledge that led administrators to feel that they could achieve no knowledge at all. Even outside the arena of international addressees, thus, legality often functioned more as an emblem of the state's desired knowledge capacity than as an acknowledged or legitimated social force. 
Administrators usually talked about their roles and goals in terms of negotiation and ambiguity, rather than in terms of clear-cut distinctions among straightforward categories of political organization. The duties, ends, and means of technocratic administration were live issues for the bureaucrats I worked with, who constantly redefined their positions within the complex and never fully definable organizations they inhabited. Indeed, invoking a schema of simply defined political categories that would render finalized or cut-and-dried (in Mandarin, dry-and-crispy, gancui 乾脆) decisions could arouse the suspicion of other administrators.

For instance, during my time at the city government, planners working for a public university in Taipei submitted a proposal to expand its facilities by constructing a new highrise building on its campus. The highrise was to be placed around a Japanese-era building that would be dismantled and moved temporarily during construction. The Japanese-era building would then be replaced in its original location, but now behind glass, inside the highrise itself. The proposal had been accepted, then suddenly reviewed and rejected as the Heritage Site and Historical Relics Evaluation Committee (Guji ji Lishijianzhu Shencha Weiyuanhui 古蹟暨歷史建築審查委員會) designated the Japanese-era building a heritage site. The designation restricted the university's right to dismantle, move, rebuild, or tear down the building. The head of one relevant city government department, 
in which the independent Heritage Committee was housed, chaired an acrimonious meeting with university representatives.

When the representatives appealed to the department head to give them room to pursue alternatives, he rejected their request in a rising voice: the decision had been taken by the Evaluation Committee, he insisted, and he could not direct (zhudao 主導) them. If he held that power, Taiwan would a society of rule-byperson (renzhi shehui 人治社會), rather than a society of rule-by-law (fazhi shehui 法治社會). As the meeting went on, a university representative encouraged the department head to compromise, appealing to their similar status: “We're all government employees (women doushi gongwuyuan 我們都是公務 員).” The department head flatly rejected this appeal to personal status and relations: "I am not the kind of government employee you're talking about. 'We're all government employees'—what do you mean by that?"xvi The meeting continued with more acrimonious exchanges and little progress.

Renzhi and fazhi, rule-by-person and rule-by-law, are old terms in Chinese political philosophy (Chen 1999; Keller 1994). In Taiwan they sometimes contrast the martial law era with the new democratic one. In the former, political power was held by individuals who were to varying extents above the laws, while under democracy, individuals implement laws that are above them. As my discussion shows, though, these terms are not as straightforward as this initial 
description suggests. For instance, Shuquan, a Department of Urban Development administrator who attended this meeting, appeared unmoved by the department head's appeals to the rule of law. A long-term administrator generally admired by colleagues for his professional skills and deep understanding of urban design, Shuquan commented that the university's plan took the old building into account, treating it very respectfully (hen zunzhongde duidai 很尊重的對待). But beyond differences of opinion about urban design, Shuquan mistrusted the department head's invocations of legality as legitimation.

Every relevant department, Shuquan explained, had deliberated (shenyi 審 議) over this case (anzi 案子) and approved it. The work was about get started when someone, a scholar with a certain status-Shuquan carefully noted that he was not telling me who it was - demanded that the city government protect this building as a heritage site. We don't know what this person's real motivation was, Shuquan continued, but it was clear that if this building were declared a heritage site, the whole plan would have to be scrapped and the university would lose the government subsidy to improve its campus, since such subsidies are given for specific projects at specific locations.

Moreover, the president of this public university was coming up for reappointment by the central government committee in charge of public education, and losing this subsidy would jeopardize his chances. Shuquan diplomatically 
emphasized that he don't know the complainant's real motivation; but he did know that the complainant was a scholar at another university. Administrators assigned to the project had not raised this issue when they'd deliberated over the plan in the first place; but when a well-known scholar complained, they suddenly became very active (jiji 積極). “I’m pretty sure," Shuquan commented with exasperated sarcasm, "that if I as an ordinary citizen write a letter today to say some building should be preserved, they definitely wouldn't pay attention to me; they'd think I was a madman."xvii

All this aroused his indignation at the department head's clear distinction of rule-by-man from rule-by-law and by his insistence that he was powerless to affect the heritage designation decision. "What's that supposed to mean?" Shuquan scoffed. "A department head doesn't have the right (power) to get things done-what does that mean? Anyway if he doesn't have the right (power), then who does?'’xvii For Shuquan, the department head's invocation of clear-cut political distinctions was disingenuous. To claim that someone in his position lacked the power he claimed to lack was laughably false, and his claim to this effect transparently utilitarian. The ideal of rule-by-law, Shuquan's response suggested, is something invoked by people to justify their own rule-by-person conduct. Moreover, the idea of removing a high-level administrator from a sphere of administration relevant to his department did not, for Shuquan, suggest a salutary democratic separation of powers. Rather, it suggested a power vacuum. 
In contrast to this brittle and misleading quality of the law, administrators spoke of themselves as tied through bonds of emotion. Speaking at the end of the regional planning meeting described above, the representative from the nearby city of Keelung (Jilong 基隆) summed up his position. “When I first met [Mr. Ke, the Taipei administrator promoting regional cooperation]," he said, "I said to him: it takes twenty minutes to get from Taipei to Keelung by car, but in terms of feelings, it's very far away. Now that we've gotten connected emotionally (lianluo ganqing 聯絡感情), well, it feels very close.”xix The phrase lianluo ganqing, which combines a word for 'communicate, contact' with a term for 'emotion,' was often used in these situations to mean 'to get closer' or 'become friendly.' To lianluo ganqing was often the explicitly stated aim of convening meetings, especially those that brought together administrators from different areas of the bureaucracy. This emphasis on emotional congruence came to the fore often as administrators found ways around the systemic difficulties of administrative functioning through personal relationships and affective attachments. Indeed, wide, dense social networks and the ability to get along with people were explicitly acknowledged as being invaluable to bureaucratic work. This fact was for the most part not presented as a failing of an insufficiently rational bureaucratic system but rather as a sign that bureaucrats conformed to widely held ethical and social norms that favored ongoing relations of mutual aid over objective, standardized processes. 
For administrators dealing with other administrators, then, the law often provided as a cover for unethical or unreasonable behavior. Insisting on a strict application of the law could raise or reinforce suspicions about an administrator's actions, rather than legitimate them. Administrators found the written law itself similarly ambiguous and untrustworthy. Far from lending certainty to administrative actions, the structure of urban planning laws was seen to confound predictability. Ideas of legality inherited from the colonial and postcolonial eras left administrators regulating a society that appeared chaotic and unknowable when judged by reference to an ideal, unrealistically perfect, legal structure.

\section{ADMINISTRATION AS SOCIAL ACTOR}

Democratization altered the way that the Taipei city government bureaucracy interacted with the people under its administrative purview. This historic process had put administrators under new, competing pressures. In the English-language literature, the important transformation of the 1980s and ' $90 \mathrm{~s}$ in Taiwan is typically described as the end of martial law, a transition from dictatorship to democracy that hit full force when the suspension of the constitution ended in 1986-87, with aftershocks in 1996 (first popular presidential election) and 2000 (first inter-party handover of presidential power).

This periodization was, however, almost never used by my Taiwanese interlocutors. Outside the government, almost nobody I knew remembered the 
dates of such supposedly key events as the lifting of martial law. In the informal historiography of everyday reference, the entire martial law period often appeared tinted in one consistent hue - a charcoal grey stability, a bullfight red repression - lent by the speaker's political position. This suggests that most people in most cases found the general tenor of a time period more relevant to their lives, and more memorable, than point-like events such as the transition from martial law to constitution or from appointed to elected government. Some pointlike events did however work as a viable synecdoche for political change when the speakers were people affected by them in narrow and specific ways, like those who worked in the city government.

The widely acknowledged political watershed in City Hall was, accordingly, not the end of martial law or democratization in general but specifically the changed status of the mayor. In 1967, after a non-KMT mayor won election for a second term, Taipei had been redesignated a provincially administered city, its mayors appointed by the central government (Rigger 1999, 2001). Elections were reinstated in 1994. The standard Mandarin word for election, xuanju 選舉, combines the characters 'to choose' and 'to recommend' (also used in terms for 'to organize'). But administrators usually referred to the relevant point-like event not as xuanju, 'election,' but as the transition to a 'mayor chosen (or elected) by the people (shizhang minxuan 市長民選)' or just 'choice (or election) by the people (minxuan 民選).' 
Elected mayors were credited by administrators with changing the tenor of the bureaucracy and putting government in closer touch with citizens' needs. But elections themselves were not seen to inherently promote either the efficient or the standardized application of laws and policies. Before the 1990s, government budgets were planned in secret with little input from the legislatures (Tan 2000). Democratization had brought a sharp decline in administrative autonomy from elected bodies, and the Taipei City Council now decides on the government's budgets. Administrators are painfully aware of city councilors' control over their ability to implement projects, and city councilors have considerable influence with individual administrators - especially the lower-level bureaucrats typically in charge of street-level order-keeping, who worry about making trouble for their department head.

In Taiwan's rather complicated electoral system (single, nontransferable votes in multi-member districts, described in detail by Rigger 1999) and highly social electoral culture (Lerman 1978), City Council members are closely tied to individual constituents through both their own unending social activity and the efforts of their vote-gatherers or ward captains (“support posts,” bangzhuang 幫 椿 in Mandarin, thiau-ah kha in Minnanese). ${ }^{\mathrm{xx}}$ Elected representatives are expected to offer all kinds of help to their constituents, including not only policies that benefit the locality or constituents' major business interests, but also various kinds of highly personalized pork: representatives are expected to find people 
jobs, to lend them money, to try to get their children into good schools and their parents into good hospitals. Of course, one way that elected representatives can show their appreciation for constituents is to help them get around regulatory restrictions by, for instance, putting pressure on administrators in the Department of Urban Development not to cite a constituent's illegal structure, or convincing people in the Department of Public Works not to tear it down.

Administrators generally talked about the Taipei City Council, an elected body, as a glitch in the progress of technocracy. People in the bureaucracy usually treated personal corruption on the part of other administrators as a localized personality trait rather than a systemic factor. In contrast, one of the major ongoing obstacles administrators cited to implementing regulations was guanshuo 關說, or informal lobbying by members of the city council—the directly elected representatives of the people — on behalf of their constituents. ${ }^{\text {xxi }}$ Many administrators complained about continual pressure to bend the rules for just one more voter.

Popular elections also had a different set of important consequences for administrators: they rendered departmental priorities unstable and long-term planning impossible. There had only been two elected mayors in Taipei during the time of my fieldwork: Chen Shui-bian (1994-1998) and Ma Ying-jeou (19982006). ${ }^{\text {xii }}$ But administrators assumed that an incoming elected official would run his bureaucracy like a fiefdom: a new mayor was expected to scrap plans made by 
a predecessor, including those designed and funded for implementation over a number of years. Almost twenty years after the disaggregation of party from state, there were still a kind of one-to-one correlation between them-albeit now one that worked on a four-year election cycle. The fact that the one-to-one correspondence of party to state could now periodically involve new and different parties only made government process less predictable (cf. Tan 2000). Thus the very process that is often seen to legitimate legal strictures in a democracy - the popular election of representatives to legislate and to execute legislation — was also a source of partiality and unpredictability that obstructed administrators' attempts at regulation.

Elections, in sum, led to inevitable instability. For the administrator, this translated into uncertainty and frustration, the demise of long-term vision, and the cluttering of professional craft with work that was done just for show. Elections pitted the bureaucratic administration against the elected legislature in ways that could leave technocrats powerless to enforce regulations because the personalistic influence of individual constituents was built into the system through the practice of voting. At the same time, elections subjected administrators and the city government as an institution to a new, and in a sense opposed, kind of pressure: the need to legitimate themselves and justify their actions in the eyes of a sometimes suspicious, and increasingly demanding, electorate. The pressure of these demands was gently remarked on in a meeting where an elderly community 
activist admonished a group of administrators to be a little more liberal with their spending on cultural preservation: "Cultural things just do require spending money." A high-level DUD employee agreed but qualified: "But when you spend money you want to spend it so that people praise you, not so they scold you." "xxiii Rather than enforcing or invoking clearly stipulated and straightforwardly implementable laws, department administrators spent much of their time talking to people. Administrators were constantly preparing for and holding meetings with residents of localities under their purview. One of the most common types was the 'explanatory meeting (shuominghui 說明會),' a name that harks back to an era when government administrators were more free to simply 'explain' their plans to the affected people. These days, shuominghui are more likely to be about reaching a compromise than sharing information.

For instance, Maokong (貓空) is a mountainous tea-growing area of Taipei zoned as farmland (nongye qu 農業區), which entails heavy restrictions on commercial activity. Nonetheless, Maokong has, for a couple of decades now, been one of Taipei's main leisure consumption areas: the mountains are crowded with teahouses and restaurants and the slim roads are chronically jammed on weekends and holidays. DUD administrators had been working for several years to bring the Maokong area under some sort of regulatory control. Local landowners pushed to retain their agricultural designation, which left their 
property taxes untouched and their activities largely unregulated, but they also agitated to receive improved public facilities. DUD administrators, in turn, felt they needed to bring some order to hillside water usage and construction before the pressure of so many busy establishments on the steeply sloped hills led to an environmental disaster.

The process of legalization was generally not described in terms of laws. As one administrator explained, persuasiveness (shuifuli 說服力) would determine the situation's resolution. The process hinged on negotiating and speaking skills—what's known as 'mouth-talent (koucai 口才).' An administrator in charge of a similar legalization process in another area expressed a typical sentiment when he said that the teahouses on Maokong arose and endure because they answer a demand (xuqiu 需求). The fact that their actual land use failed to correspond to their zoning designation was really the government's fault. Moving “too slowly," it had been overtaken by "social changes (shehui de bianqian 社會 的變遷)” like the increasing demand for leisure activities by Taipei’s increasingly wealthy population. Negotiating and compromising with the business owners in order to legalize these businesses, he explained, was the government's duty or responsibility (zeren 責任).

A large meeting with landowners from Maokong started out with an attempt to connect the participants emotionally through the medium of food, an 
indispensable part of almost any Taiwanese social interaction. The participants joined in a multi-course lunchtime banquet, after which the DUD section head in charge of the case hopped up on stage and took the microphone. Engaging in public negotiation with the several hundred local landowners who faced him, he answered questions even as he issued pleas and offered promises. As landowners came up to ask questions, express opinions, and occasionally berate him and his administrative system, the section head outlined not the clear boundaries of legality or the unilateral demands of governance but a shifting ground of compromise. "The best way is for us all to retreat (step back)," he said.

"Landowners (farmers) retreat a step, and the city government retreats a step."xxiv People involved in planning negotiations in Taipei sometimes complained about the slow pace of government action. But part of the background for this pace was precisely the constant negotiations, mutual accommodation, and synchronized retreat that the section head's plea outlined.

Even seemingly straightforward implementations of regulation turned out to position the city government principally not within a web of laws but as part of a network of interdependent social actors. Though city government departments concerned with spatial management can be quite proactive, their regulatory enforcement tends to be reactive: it usually takes a complaint, or several, to make them swing into action. Given the likelihood of the kind of interference from elected officials mentioned above and the general bother of tearing things down 
and incurring the anger of the people who built them, even a complaint that was not intercepted by some sort of pressure was always likely to be simply shelved.

This option becomes more complicates when people lodge their complaints via the internet, however. Internet complaints can be tracked by their (importantly, anonymous) lodgers. Faced with this new situation, an administrator told me, the department in charge of tearing down illegal structures had instituted a new, unofficial but standard, response procedure. After ascertaining the veracity of a complaint, an administrator would contact the offending parties and advise them to figure out which of their neighbors they had offended. If someone was going so far as to complain to the city government, the reasoning went, the offending parties clearly were not managing their social relations very well. A warning from a neutral source might give them a chance to ameliorate the situation, defusing the problem and letting the department off the hook.

If another complaint was filed, though, "there's nothing we can do (mei banfa 沒辦法).” The department would then tear the thing down, if only to avoid the risk of itself becoming the target of resident complaints. ${ }^{\mathrm{xxv}}$ While these steps might appear to increase legal standardization, they were phrased and justified in the ethical terminology of interpersonal relations. A direct, anonymous complaint to the city government signaled a breakdown of the ethical norms of interpersonal relations among the parties involved. The bureaucracy's primary job was to act as a broker in this interpersonal arena, assisting with the reestablishment of normal 
relations. Its subsequent taking on of an assertively regulatory role was explained in terms of its interpersonal (so to speak) relations with complainants: the bureaucracy, too, had a social role to play.

When addressing those outside the bureaucracy, thus, administrators often resorted to nonlegal justifications for their attempts to implement legal strictures. In some situations, as with the internet complaints, the law pushed administrators to play an ameliorative, consensus-building social role. Implementing zoning regulations by actually tearing down illegal structures was also an admission of failure in fulfilling this social role. Administrators assumed that they must cajole and convince people outside the government to agree to come within their regulative scope. Their negotiations with outsiders largely figured the government not as wielding the might of legitimated control but as vying for legitimation from outsiders. While the personalistic ethos of the regime patronage system still permeated administrative actions, administrators were now likely to perceive themselves not as patrons but as clients of their constituents.

\section{CONCLUSION}

As I have detailed above, administrative conceptions of law in Taiwan tend to differ by object or addressee. At the level of international organization, law is figured as an emblem that need bear little relation with actual situations on the ground. The existence of a western-style legal and regulatory system functions 
as a kind of symbol of modernity and of Taiwan's right to take a place in the community of nation-states. At the level of inter-administrator interaction, the law is often perceived as too inflexible to yield realistic results and too manipulable to provided a trustworthy justification for action. In interactions between administrators and others outside the bureaucracy, law appears sometimes as an impetus to correct social action, sometimes as a boundary that exposes administrative failure. Often, as administrators plead with people to come into the regulative fold, law barely makes an appearance at all.

Administrators often see law as too hard or inflexible to be well suited to regulating actual social life. Perhaps somewhat paradoxically, this very inflexibility helps render legality a field of negotiation. The people I worked with regarded both the written law and law in action as aspects of the sociopolitical process of compromise that typified government action, rather than as a superordinate or rationalized repository of general values. Attempts to implement the kind of election-based representativeness or legally regulated transparency required by common notions of the rule of law sometimes obstruct the implementation of regulations. And reaching consensus - rather than delineating rights and responsibilities or forging contractual obligations - is the stated goal of most of the acrimonious government-based meetings I saw. The administrators I knew were more likely to draw their models for understanding and behaving in the world from an ethical realm that privileged the maintenance of correct 
relationships with others, the fulfillment of interpersonal responsibilities, and the striving for consensus, rather than a legalistic conception of justice as impartial equality. Indeed, the law itself often needed support from other realms for justification.

It may be that the discourse of law-derived in Taiwan as in many places from Euro-American models - is often seen to attempt to encompass all human action and to permeate people's conceptions of their own actions. But as I've described, in Taipei even the people delegated to implement the law find the very legitimacy of the law questionable. They answer this question differently in different situations - differences that can best be understood not by looking for an overarching, consistent notion of legality but by following their own understanding of law as embedded within other, in this case more powerful, social values. 


\section{REFERENCES}

Albrow, Martin. 1970. Bureaucracy. New York: Praeger Publishers.

Allen, Joseph. 2000. Reading Taipei: Cultural Traces in a Cityscape. Harvard

Studies on Taiwan: Papers of the Taiwan Studies Workshop 3:1-23.

------. 2005. Mapping Taipei: Representation and Ideology, 1626-1945. Studies on Asia Series III 2(2):59-80.

Amsden, Alice. 1985. The State and Taiwan's Economic Development. In

Bringing the State Back in, eds Peter B. Evans, Dietrich Rueschemeyer, and

Theda Skocpol. Cambridge: Cambridge University Press.

Arendt, Hannah. 1959. The Human Condition: A Study of the Central Dilemmas

Facing Modern Man. Garden City NY: Doubleday Anchor.

Bernstein, Anya. 2007. Why "Taiwan is Too Democratic": Legitimation, Administration, and Political Participation in Taipei. Ph.D. diss. Department of Anthropology, University of Chicago, Chicago, Il.

Bishai, Martha Fitzpatrick. 1991. The Development of Industrial Land in Taiwan:

A Legal Framework for State Control. Journal of Developing Areas 26:53-64.

Blau, Peter M. 1963. The Dynamics of Bureaucracy: A Study of Interpersonal Relations in Two Government Agencies. Chicago: University of Chicago Press. 
Bosco, Joseph1992. 1992. Taiwan Factions: Guanxi, Patronage, and the State in Local Politics. Ethnology 31(2):157-184.

Bourdieu, Pierre. 1995. Rites of Institution. In Language and Symbolic Power, ed John B. Thompson. Gino Raymond and Matthew Adamson, trans. Pp. 117-126. Cambridge MA: Harvard University Press.

Brubaker, Rogers. 1996. Nationalism Reframed: Nationhood and the National Question in the New Europe. Cambridge: Cambridge University Press. Burchell, Graham, Colin Gordon, and Peter Miller, eds. 1991. The Foucault Effect: Studies in Governmentality. Chicago: University of Chicago Press. Chang, Han-Yu and Ramon H. Myers. 1963. Japanese Colonial Development Policy in Taiwan, 1895-1906: A Case of Bureaucratic Entrepreneurship. Journal of Asian Studies 22(4):433-449.

Chang, Ly-Yun 張笠雲, Yu-Hsia Lu 呂玉瑕, and Fu-Chang Wang 王甫昌, eds. 1997. 九 0 年代的台灣社會：社會變遷基本調查研究系列二（上） Taiwanese Society in the 1990S: Taiwan Social Change Survey Symposium Series 2 (Part 1). Taipei: 中央研究院社會學研究所籌備處 The Preparatory Office of the Institute of Sociology, Academia Sinica. Chang, Mau-kuei. 1994. Toward an Understanding of the Sheng-Chi Wen-Ti in Taiwan: Focusing on Changes After Political Liberalization. In Ethnicity in 
Taiwan: Social, Historical, and Cultural Perspectives, eds Chung-min Chen, Ying-chang Chuang, and Shu-min Huang. Pp. 93-150. Taipei: Institute of Ethnology, Academia Sinica.

Chao, Linda and Ramon H. Meyers. 1998. The First Chinese Democracy:

Political Life in the Republic of China. Baltimore: Johns Hopkins University Press.

Chen, Albert H. Y. 1999. Towards a Legal Enlightenment: Discussion in Contemporary China on the Rule of Law. Pacific Basin Law Journal 17:125-165. Cohn, Bernard. 1987. The Census, Social Structure, and Objectification in South Asia. In An Anthropologist Among the Historians and Other Essays, ed Delhi: Oxford University Press.

Comaroff, John and Jean Comaroff. 1992. Ethnography and the Historical Imagination. Boulder: Westview Press.

Corcuff, Stephane. 2000. Taiwan's 'Maindlanders': A New Ethnic Category. China Perspectives 28:71-81.

Corcuff, Stephane, ed. 2002. Memories of the Future: National Identity Issues and the Search for a New Taiwan. Armonk NY: M.E. Sharpe. Cumings, Bruce. 1984. The Origins and Development of the Northeast Asian Political Economy: Industrial Sectors, Product Cycles and Political Consequences. International Organization 38(1):1-40. 
du Gay, Paul. 2000. In Praise of Bureaucracy: Weber, Organization, Ethics. London: Sage.

Duara, Prasenjit. 1988. Superscribing Symbols: The Myth of Guandi, Chinese God of War. Journal of Asian Studies 47(4):778-795.

Errington, Joseph. 1995. State Speech for Peripheral Publics in Java. Pragmatics $5(2): 213-224$.

Eskildsen, Robert. 2005. Taiwan: A Periphery in Search of a Narrative. Journal of Asian Studies 64(2):281-294.

Espeland, Wendy Nelson. 1998. The Struggle for Water: Politics, Rationality, and Identity in the American Southwest. Chicago: University of Chicago Press.

Feldman, Eric A. 2000. The Ritual of Rights in Japan: Law, Society, and Health Policy. Cambridge: Cambridge University Press.

Foucault, Michel. 1977. Discipline and Punish: The Birth of the Prison. Alan Sheridan, trans. New York: Vintage.

------. 1980. Two Lectures. In Power/Knowledge: Selected Interviews and Other Writings 1972-1977, ed Colin Gordon. Pp. 78-108. New York: Pantheon.

-----. 1991. Governmentality. In The Foucault Effect: Studies in

Governmentality, ed Colin Gordon Graham Burchell, and Peter Miller. Chicago: University of Chicago Press.

Gal, Susan. 1991. Bartok's Funeral: Representations of Europe in Hungarian Political Rhetoric. American Ethnologist 18:440-458. 
Gladney, Dru C. 1993. Representing Nationality in China: Refiguring Majority/Minority Identities. Journal of Asian Studies 53(1):92-123.

Gold, Thomas B. 1986. State and Society in the Taiwan Miracle. Armonk, N.Y.: M.E. Sharpe.

Hacking, Ian. 1990. The Taming of Chance. Cambridge: Cambridge University Press.

------. 1991. How Should We Do the History of Statistics? In The Foucault Effect: Studies in Governmentality, ed Colin Gordon Graham Burchell, and Peter Miller. Chicago: University of Chicago Press.

------. 1999. Making Up People. In The Science Studies Reader, ed Mario Biagioli. NYC, London: Routledge.

Handelman, Don. 2004. Nationalism and the Israeli State: Bureaucratic Logic in Public Events. Oxford: Berg.

Hansen, Thomas Blom. 2001. Wages of Violence: Naming and Identity in Postcolonial Bombay. Princeton: Princeton University Press.

Herzfeld, Michael. 1992. The Social Production of Indifference: Exploring the Symbolic Roots of Western Bureaucracy. New York: Berg. Ho, Samuel P. S. 1968. Agricultural Transformation Under Colonialism: The Case of Taiwan. Journal of Economic History 28(3):313-340. 
-----. 1971. The Development of Japanese Colonial Government in Taiwan, 1895-1945. In Government and Economic Development, ed Gustaf Ranis. Pp. 287-328. New Haven: Yale University Press.

-----. 1978. Economic Development of Taiwan, 1860-1970. New Haven: Yale University Press.

-----. 1987. Economics, Economic Bureaucracy and Taiwan's Economic Development. Pacific Affairs 20:226-247.

Honig, Bonnie. 1993. Political Theory and the Displacement of Politics. Ithaca: Cornell University Press.

Huang, Wuda 黃武達. 1998. 日治時代(1895-1945) 臺北市之近代都市計畫 [Rizhishidai (1895-1945) Taibeishi Zhi Jindai Dushijihua]. Contemporary Taipei City Planning in Japanese Colonial Age. 臺北縣板橋市 Banqiao City: 臺彎都市 史研究室 Taiwan Urban History Research Center.

Huang, Yuyuan 黃宇元. 1983. 臺北市發展史 [Taibeishi Fazhanshi]. (Taipei

Urban Development History). Taipei: 臺北市文獻委員會 Taipei City Historical Records Committee. 
Hull, Matthew S. 2003. Paper Travails: Bureaucracy, Graphic Artifacts, and the Built Environment in the Islamabad Metropolitan Area, 1959-1998. Department of Anthropology, University of Chicago, Chicago IL.

Hwang, Jau-yuan. 1995. Constitutional Change and Political Transition in Taiwan Since 1986 -- the Role of Legal Institutions. Harvard University, Cambridge. Jacobs, Lesley A. 2007. Rights and Quarantine During the Sars Global Health Crisis: Differentiated Legal Consciousness in Hong Kong, Shanghai, and Toronto. Law and Society Review 41:511-550.

Johnson, Marshall. 1992. Classification, Power, and Markets: The Waning of the Ethnic Division of Labor. In Taiwan: Beyond the Economic Miracle, eds Denis Fred Simon and Michael Y.M. Kau. Armonk NY: M.E. Sharpe. Ka, Chih-ming. 1995. Japanese Colonialism in Taiwan: Land Tenure, Development, and Dependency, 1895-1945. Boulder CO: Westview Press. Keller, Perry. 1994. Sources of Order in Chinese Law. The American Journal of Comparative Law 42:711-759.

Kennedy, Brian L. and Chun-Ling Shen. 2005. The Best of Times and the Worst of Times; Criminal Law Reform in Taiwan. American Journal of Chinese Studies 12(2):107-137.

Kirby, William C. 1984. Germany and Republican China. Palo Alto: Stanford University Press. 
-----. 1990. Continuity and Change in Modern China: Economic Planning on the Mainland and on Taiwan, 1943-1958. Australian Journal of Chinese Affairs

$24: 121-141$

Kuo, Cheng-tian. 2000. Taiwan's Distorted Democracy in Comparative Perspective. Journal of Asian and African Studies 35(1):85-111.

Lee, Young-ho (Yi Yeong-ho). 2004. Colonial Modernity and the Investigation of Land Customs: A Comparison of Japan, Taiwan, and Korea. Korea Journal 44(2):149-173.

Lerman, Arthur1978. 1978. Taiwan's Politics: The Provincial Assemblyman's World. Washington DC: University Press of America.

Macaulay, Stewart. 2005. The New Versus the Old Legal Realism: "Things Ain't What They Used to be". Wisconsin Law Review 365-403.

Martin, Jeffrey. 2007. A Reasonable Balance of Law and Sentiment: Social Order in Democratic Taiwan From the Policeman's Point of View. Law and Society Review 41(3):665-698.

McCormick, John P. 1997. Carl Schmitt's Critique of Liberalism: Against Politics as Technology. Cambridge: Cambridge University Press.

Myers, Ramon H. and Mark R. Peattie, eds. 1984. The Japanese Colonial Empire, 1895-1945. Princeton: Princeton University Press. 
Phillips, Steven E. 2003. Between Assimilation and Independence: The Taiwanese Encounter With Nationalist China, 1945-1950. Stanford: Stanford University Press.

Pitkin, Hannah Fenichel. 1998. The Attack of the Blob: Hannah Arendt's Concept of the Social. Chicago: University of Chicago Press.

Rigger, Shelley. 1999. Politics in Taiwan: Voting for Democracy. London:

Routledge.

------. 2000. Is Taiwan Independence Passé? Public Opinion, Party Platforms and National Identity in Taiwan. Harvard Studies on Taiwan: Papers of the Taiwan Studies Workshop 3(3):151-170.

-----. 2001. From Opposition to Power: Taiwan's Democratic Progressive Party. Boulder: Lynne Rienner.

-----. 2006. Taiwan's Rising Rationalism: Generations, Politics and "Taiwanese Nationalism." (Policy Studies 26). Washington, DC: East-West Center Press. Sahlins, Marshall. 1999. Two Or Three Things I Know About Culture. Journal of the Royal Anthropological Institute 5(3):399-421.

Schmitt, Carl. 1985a. Political Theology: Four Chapters on the Concept of Sovereignty. George Schwab, trans. Cambridge MA: MIT Press.

------. 1985b. The Crisis of Parliamentary Democracy. Ellen Kennedy, trans. Cambridge MA: MIT Press. 
-----. 2004. Legality and Legitimacy. Jeffrey Seitzer, trans. Durham, London:

Duke University Press.

Silbey, Susan S. 2005. After Legal Consciousness. Annual Review of Law and Social Science 1:323-368.

Tan, Qingshan. 2000. Democratization and Bureaucratic Restructuring in Taiwan. Studies in Comparative International Development 35(2):48-64.

Taylor, Jay. 2000. The Generalissimo's Son: Chiang Ching-Kuo and the Revolutions in China and Taiwan. Cambridge MA: Harvard University Press. Tien, Hung-mao. 1989. The Great Transformation: Political and Social Change in the Republic of China. Stanford: Hoover Institution Press.

Ts'ai, Hui-Yu Caroline 蔡慧玉. 2006. Shaping Administration in Colonial

Taiwan, 1895-1945. In Taiwan Under Japanese Colonial Rule: 1895-1945, eds Ping-Hui Liao and David Der-Wei Wang. Pp. 97-121. New York: Columbia University Press.

Valverde, Mariana. 2003. Which Side Are You on? Uses of the Everyday in Sociolegal Scholarship. PoLAR: Political and Legal Anthropology Review 26(1):86-98.

Wang, Horng-luen. 2004. National Culture and its Discontents: The Politics of Heritage and Language in Taiwan, 1949-2003. Comparative Studies in Society and History 46(4):786-815. 
Wang, Tay-sheng. 2000. Legal Reform in Taiwan Under Japanese Colonial Rule, 1895-1945: The Reception of Western Law. Seattle: Washington University Press. Weber, Max. 1978. Basic Sociological Terms. In Economy and Society: An Outline of Interpretive Sociology, ed Guenther Roth and Claus Wittich. Berkeley: University of California Press Press.

Winckler, Edwin A. 1981. Roles Linking State and Society. In The Anthropology of Taiwanese Society, eds Emily Martin Ahern and Hill Gates. Stanford: Stanford University Press.

------ 1984. Institutionalization and Participation on Taiwan: From Hard to Soft Authoritarianism? The China Quarterly 99:481-499.

Winn, Jane Kaufman. 1994. Relational Practices and the Marginalization of Law: Informal Financial Practices of Small Businesses in Taiwan. Law and Society Review 28(2):193-232.

Wong, Timothy Ka-ying. 2001. From Ethnic to Civic Nationalism: The Formation and Changing Nature of Taiwanese Identity. Asian Perspective 25(3):175-296.

Wu, Nai-teh. 1987. The Politics of a Regime Patronage System: Mobilization and Control Within an Authoritarian Regime. Department of Political Science, University of Chicago, Chicago. 
Ye Qizheng 葉啟政, Guangguo Huang 黃光國, Yuanqi Cai 蔡淵契, Xianzong

Lai 賴賢宗, and Honghui Zhang 張宏輝. 2000. “共識與多元性”對談會

("Consensus and Multiplicity" Roundtable). 思與言：人文與社會科學雜誌

Thought and Words: Journal of the Humanities and Social Science 38(3):1-43.

Yeh, Jiunn-Rong. 2002. Constitutional Reform and Democratization in Taiwan, 1945-2000. In Taiwan's Modernization in Global Perspective, ed Peter C. Y.

Chow. Pp. 47-78. Westport CT: Praeger.

Zhang, Jingsen 張景森. 1993. 臺灣的都市計畫 1895-1988 [Taiwan De

Dushijihua 1895-1988]. (Taiwan's Urban Planning 1895-1988). Taipei: 業強

Yeqiang.

${ }^{i}$ The island has been multiply and complexly colonized, starting with the Dutch East India Company's brief rule over the south (1642-1662), when the first significant numbers of agricultural migrants from southeastern China came across the Taiwan Strait to turn Taiwan into the primary sugar exporter of the Dutch colonies (Ka 1995:13). The Dutch were expelled by Koxinga, a ChineseJapanese pirate-crusader, and his descendants, who used the island as a base from which to launch attacks on the newly incumbent Qing dynasty on the mainland until the Qing itself took over Taiwan in 1683. In 1895, the Qing surrendered Taiwan to the Japanese; the legacy of their bureaucratic organization of their first colony would be as important as their early moves toward its industrialization. After the Japanese defeat in World War II, the victorious Allies transferred control of Taiwan to the KMT (the Chinese Nationalist Party), the internationally recognized authority on the mainland, which was then engaged in the endgame of 
the Chinese civil war. With the Communist victory on the mainland in 1949, the KMT retreated to Taiwan, declaring itself the legitimate government of China in exile and holding the island under martial law until 1986. Post-martial law political rhetoric sometimes refers to the KMT as another 'foreign power (wailai zhengquan 外來政權)' (see e.g. Ye Qizheng 葉啟政 et al. 2000) implying a semicolonizing status (Phillips 2003 describes early interactions between the KMT and the sociopolitical forces it found on the island).

ii DPP stands for Democratic Progressive Party, the initial opposition party formed in 1986, slightly in advance of the lifting of martial law restrictions on political party formation, by members of the opposition movement known until then as Dangwai (黨外), or "Outside the Party." KMT stands for Kuomintang (Guomindang 國民黨), whose English name is the Chinese Nationalist Party. To avoid confusion among different kinds of Chineseness and different kinds of nationalism, I use the transliterated acronym KMT.

iii The primary ethnicized divisions in Taiwan distinguish those who migrated to the island after its return to Chinese rule in 1945 from those whose ancestors had moved there over the course of the preceding three centuries. These two groups, while differentiated on the island by the term zuqun (族群, group or ethnicity), are generally acknowledged to belong to the same race (minzu, 民族). The roughly $2 \%$ of the island's population descended from indigenous inhabitants, in contrast, is spoken of as separate from this common ancestry; but this is not the main ethnicized distinction in Taiwanese politics.

iv " ....we should direct our researches on the nature of power not towards the juridical edifice of sovereignty, the State apparatuses and the ideologies which accompany them, but towards domination and the material operators of power, towards forms of subjection and the inflections and utilizations of their localized systems, and towards strategic apparatuses. We must eschew the model of Leviathan in the study of power. We must escape from the limited field of juridical sovereignty and State institutions, and instead base our analysis of power on the study of the techniques and tactics of domination" (Foucault 1980:102). ${ }^{v}$ As Peter Blau (1963:276) suggests, people who study bureaucracy are likely to end up in relatively open and flexible parts of it. "Suppose someone wants to study bureaucratic rigidities and fear of innovation. The very fact that management gives him permission to conduct his investigation in the organization indicates that it is not resistant to trying something new." This is certainly true of the Department of Urban Development, were administrators at all levels of the department hierarchy acted welcoming of my presence and willing to entertain my questions. 
vi "Probably none of us would be willing the bear the costs of $100 \%$ enforcement of all the laws all the time. On the one hand, we rely on police and prosecutorial discretion to tailor the law to fit real situations not anticipated by the legislature. ... On the other hand, full enforcement would entail many costs ... [to] privacy and civil liberties" (2005:390).

vii This view is shared by other theorists of the political, notably Carl Schmitt (1985a; 1985b; 2004; see also McCormick 1997) and perhaps Weber (though see du Gay 2000 for an alternative interpretation of Weber's moral evaluation of bureaucracy). It may be worth noting that these persuasive critics of administrative governance come from overlapping places and times.

viiiHonig (1993:82) suggests something similar: Arendt's categories of action may be defined less by a sphere of activity than by a "mentality... characteristic of" certain kinds of activities.

${ }^{\text {ix }}$ All names in this article are pseudonyms. Naming conventions reflect my own relations to the people involved: superiors, whom I addressed by family name and departmental position, are presented here by family name preceded by Mr. or Ms., while those of equal rank, whom I addressed by given names or family name and given name, are presented here as such as well.

$\mathrm{x}$ “我們最喜歡抄你們的, 因為最熟...他們本來抄歐洲的, 那我們因為很近所 以就抄他們的.”

${ }^{\mathrm{xi}} \mathrm{Wu}$ finds that martial law era Taiwan had a bifurcated elite structure in which national (or Party) level elites were separated from local-level political elites (or factions) both demographically (the former were predominantly mainlanders, the latter Minnanese) and in terms of recruitment to the system (the former through kinship and acquaintance in the Party, the later through local social networks), and that local elites almost never made it into the ranks of national elites.

xii Shelley Rigger (2000) rightly points out the "post-nationalist" stance of many Taiwanese people, who care more about "autonomy" (possessing and controlling a separate state and economy) than formal "sovereignty" (the de jure recognition of that separation). As she details, this helps explain why for the majority of Taiwanese, the "answer to the question 'Do you prefer independence or unification?' is 'no'” (Rigger 2000:152-153). Formal sovereignty and unification are, as Rigger suggests, much more important as handy extreme poles for political discourse than as actual political preferences. Still, city administrators, perhaps more than most people, took both actual autonomy and potential sovereignty into account.

xiii “我們沒有共識... 連討論臺北應該怎麼樣討論不下去. 臺北是不是首都? 它 當然是首都. 你敢不敢講這是首都? 不敢講.... 連一個在山坡地我們要不要個 斜屋頂 ... 連這個都沒辦法有共識. 也是爭了好幾年” (Interview with Mr. Wei, Department of Urban Development administrator, 11\05\03). 
xiv Interview with Ms. Zhu, Department of Urban Development administrator, $09 \backslash 09 \backslash 04$.

${ }^{\mathrm{xv}}$ This is not to say the laws have not had any effect at all. Although they have not successfully determined actual land uses of existing buildings, zoning regulations have helped the city government control the size of newly constructed buildings, whose footprint-to-area ratio is partly determined by the zoning of the land plot. (New construction is, of course, much easier to track than the use of particular rooms in existing buildings.) The regulations have also given rise to constant landlord petitions to designate their area a commercial zone, which predictably increases the value of the land in Taipei's agile and speculation-prone real estate market. According to other sources, such as a friend who opened a business in a residential area, another effect of zoning regulations has been to provide local police officers, who are the most likely to be aware of land-use violations on their beats, with an opportunity to increase their informal profits by promising to neglect to report a violation. In practice it seemed that such bribes were usually asked only of highly restricted businesses on the edge of legality to begin with, such as hostess bars, video game gambling parlors, and the like, whose owners often paid the local organized crime unit as well.

xvi “你不要暗示社麼, 你要說明白. 我不是你說的那種公務員. 《我們都是公 務員》，你是甚麼意思呢?”

xvii “我相信我這個市民小老百姓今天寫信來說, 某個房子要保護, 他一定不理 我, 他以為我是瘋子.”

xviii “怎麼可能? 局長沒有權利做事怎麼可能? 再說他沒有權利誰有權利呢?” The first question, repeated later, means "how is that possible?" But colloquial usage (and the typical tone of voice used with it) places it closer to something coarser in English.

xix “跟 [咳先生]第一次接觸跟他講, 臺北到基隆車上二十分鐘可是感覺上很遠 的. 那現在聯絡感情就覺得很近.”

${ }^{x x}$ What I call Minnanese here is the local language or dialect on Taiwan, usually known as Taiwanese (Taiwanhua 臺彎話, Taiyu 台語) or Southern Min (Minnanyu 閩南語), which coexists with the official language of Mandarin, which is known in Taiwan as "the national language (Guoyu 國語)." I use the term Minnanese as a way of trying to sidestep the implications that the other terms can be seen to have about the speaker's opinion on the relationship between Taiwan and the PRC. Thanks to Cheng-Yi Huang 黃承儀 for this suggestion. ${ }^{x x i}$ No laws acknowledge or regulate formal lobbying in Taiwan (Tan 2000). Some administrators compared this situation unfavorably to that of the U.S., where, they felt, explicit legal recognition of lobbying made it easier to perhaps to control. This judgment no doubt had to do with the common image of the US as a largely 
law-abiding and, as one administrator put it, relatively simple or innocent (danchun 單純) society.

xxii Hau Lung-bin (Hao Longbin 郝龍斌), a KMT candidate, was elected mayor in December 2006.

xxiii، 文化的東西本來要花錢; ”“花錢要花得讓人家成長而不是被人家罵.”

xxiv “....siong ho e banhua si nng e long 退步, 農民退一步, 市政府也退一步” (the romanized part is in Minnanese).

${ }^{x x v}$ Jeffrey Martin (2007) describes a similar but more complex situation outside of the capital city, where a police officer responsible for fining an unlicensed food stand manipulates evidence in order to avoid disrupting the status quo of busy market life. The impulse Martin describes, however, is similar: the police officer mediates between offender and complainer, encouraging them to come to an understanding. The force of the law is less what the police officer imposes on them than it is an impetus for him to encourage this reconciliation. Matthew Hull (2003) explains why administrators might be resistant to the incursion into their areas of knowledge and control that the internet represents, but I did not see such resistance myself. 